\title{
KARAKTERISTIK MIKROBA DAN KIMIA SOSIS AYAM DENGAN PENAMBAHAN KHITOSAN DAN ANGKAK YANG DISIMPAN PADA REFRIGERATOR
}

\section{MICROBE AND CHEMICAL CHARACTERISTICS OF CHICKEN SAUSAGE WITH CHITOSAN AND ANKA RICE ADDITION STORED IN THE REFRIGERATOR}

\author{
Nia Vergiyana*, Rusman, dan Supadmo \\ Fakultas Peternakan, Universitas Gadjah Mada, Jl. Fauna No. 3, Bulaksumur, Yogyakarta, 55281
}

\section{INTISARI}

Zat pengawet dan pewarna alami yang ditambahkan pada produk olahan daging aman untuk dikonsumsi. Penelitian ini bertujuan untuk mengetahui pengaruh penambahan khitosan dan angkak ke dalam sosis ayam sebagai zat antibakteri berdasarkan karakteristik mikrobiologi dan kimia sosis ayam sampai penyimpanan 21 hari pada refrigerator. Rasio penambahan angkak (w/w) dan khitosan (w/v) masing-masing $0 ; 0,5 ; 1 ; 1,5 ; 2 \%$. Khitosan dilarutkan dalam asam asetat $1 \%$. Penyimpanan dilakukan sampai 21 hari pada refrigerator dengan pengamatan 0,7 , 14, dan 21 hari. Variabel yang diamati meliputi aktivitas antibakteri, karakteristik mikroba (Enterobactericeae, dan Salmonella) dan kimia (kadar air, protein, lemak, dan aktivitas antioksidan). Data aktivitas antibakteri dianalisis dengan Randomized Completely Block Design (RCBD), Enterobacteriaceae dengan One-Way ANOVA, karakteristik kimia dan mikrobiologi dianalisis menggunakan analisis variansi pola faktorial $4 \times 5$ dengan faktor lama penyimpanan dan kombinasi konsentrasi khitosan:angkak dan dilanjutkan dengan Duncan's Multiple Range Test (DMRT). Setiap perlakuan diulang sebanyak 3 kali. Penambahan khitosan dan angkak sampai $2 \%$ dapat meningkatkan aktivitas antioksidan dan antibakteri khitosan yaitu $1,92 \%$ dan $3,06 \mathrm{~mm}$, tetapi menurunkan kadar air 2,54\%. Lama penyimpanan sosis sampai 21 hari pada refrigerator meningkatkan aktivitas antioksidan yaitu 6,25\%. Penambahan khitosan:angkak dan lama penyimpanan sampai 21 hari tidak mengubah kadar protein dan lemak. Total Enterobacteriaceae terdeteksi pada hari ke-21 tetapi populasi masih sangat rendah $\left(<30,0 \times 10^{1} \mathrm{CFU} / \mathrm{g}\right)$, Salmonella tidak menunjukkan adanya populasi sampai 21 hari. Berdasarkan hasil dapat disimpulkan bahwa lama penyimpanan sosis ayam yang ditambah khitosan dan angkak pada refrigerator sampai 21 hari masih layak untuk dikonsumsi.

(Kata kunci: Sosis, Khitosan, Angkak, Refrigerator, Kimia, Mikrobiologi)

\begin{abstract}
Natural preservatives and colorants that are added to processed meat products are safe for consumption. This research was conducted to study the effect of chitosan and anka rice addition to chicken sausage as antibacterial agent on microbiology and chemical characteristics of chicken sausage up to 21 d of storage in the refrigerator. The ratio anka rice $(w / w)$ and chitosan $(w / v)$ were $0 ; 0.5 ; 1 ; 1.5 ; 2 \%$, respectively. Chitosan was diluted to $1 \%$ acetic acid. Length of storage up to 21d in the refrigerator was observed at 0, 7, 14 and 21d. The observed variables were antibacterial activity, microbe characteristic (Enterobacteriaceae, and Salmonella) and chemical (moisture, protein, fat content and antioxidant activity). Data of antibacterial activity were analyzed with Randomized Completely Block Design (RCBD), Enterobacteriaceae with One-Way ANOVA, data were analyzed using variance analysis of factorial pattern $4 \times 5$ with factors length of storage and concentration of combination chitosan:anka rice and followed by Duncan's Multiple range Test (DMRT). Each treatment was done for three replications. Chitosan and anka rice additions up to $2 \%$ increased antioxidant activity and chitosan antibacterial as much as $1.92 \%$ and $3.06 \mathrm{~mm}$, but decreased moisture 2.54\%. Length of storage of sausage up to $21 d$ in the refrigerator increased antioxidant activity around $6.25 \%$. Chitosan:anka rice addition and length of storegae up to 21 d did not change protein content and fat. Enterobacteriaceae was detected on $21 d$ but the population still very low $\left(<30,0 \times 10^{1}\right.$ CFU/g), Salmonella was not detected up to $21 d$. Based on the result it could be concluded lengthen the chicken sausage's quality in the refrigerator up to 21 could be consumed.
\end{abstract}

(Key words: Sausage, Chitosan, Anka rice, Refrigerator, Chemical, Microbiology)

\footnotetext{
* Korespondensi (corresponding author):

Telp. +62 85741806424

E-mail: niavergiyana@gmail.com
} 


\section{Pendahuluan}

Sosis merupakan salah satu produk olahan daging yang digemari oleh masyarakat. Penyimpanan produk olahan daging akan mempengaruhi kualitas mutu produk yang akan dikonsumsi masyarakat. Sosis masak hanya dapat bertahan 1 sampai 2 hari pada suhu ruang. Kualitas sosis dapat dipertahankan dengan penyimpanan suhu rendah, pada suhu dingin minimal 2 minggu dengan kemasan vakum belum terbuka dan selama 1 minggu dengan kemasan non vakum (Busboom dan Field, 2003).

Khitosan merupakan hasil deasetilasi senyawa khitin yang terdapat pada cangkang hewan golongan Crustacea (udang dan kepiting) (Suyatma et al., 2004). Khitosan memiliki sifat antimikrobia dengan mekanisme kerja mengikat membran luar dan menghilangkan fungsi barier membran sel, sehingga sel mengalami perubahan permukaan sel dan kehilangan fungsi pelindung dalam sel bakteri tersebut (Helander et al., 2001). Ion positif pada khitosan memberikan kemampuan mengikat lemak yang bermuatan negatif (Li et al., 1992).

Angkak merupakan beras berwarna merah hasil fermentasi beras menggunakan kapang Monascus sp. yang menghasilkan pigmen warna merah. Angkak memproduksi senyawa antimikrobia monasidin $A$ yang saat ini lebih dikenal sebagi sitrinin (Hajjaj et al., 1999). Menurut Gremmels et al. (1991) pengamatan terhadap efek bakteriostatik mempertimbangkan penggunaan angkak sebagai pengganti nitrit untuk preservasi dan pewarna pada daging.

Penambahan khitosan dan angkak dengan penyimpanan suhu rendah pada sosis ayam diharapkan mampu mempertahankan kualitas sosis masak sampai penyimpanan 21 hari. Berdasarkan uraian tersebut, perlu dilakukan penelitian yang bertujuan untuk mengetahui pengaruh penambahan khitosan dan angkak terhadap kualitas mikrobiologi dan kimia sosis ayam yang disimpan sampai 21 hari di refrigerator. Manfaat yang diharapkan dapat memberikan informasi kepada masyarakat tentang penggunaan khitosan dan angkak sebagai pengawet dan pewarna alami.

\section{Materi dan Metode}

\section{Materi}

Alat yang digunakan untuk pembuatan sosis yaitu timbangan elektrik, grinder, pisau, panci, kompor, dan stuffer. Uji aktivitas antibakteri, karakteristik mikrobiologi, dan kimia menggunakan alat cawan, timbangan analitik, desikator, oven, tabung kjeltec, erlenmeyer, alat destruksi, destilasi, buret, kertas saring, oven, Soxhlet, mikropipet, spektrofotometer, jangka sorong, stirer, laminar air flow, autoklaf, alat membuat sumuran, dan alat-alat gelas.

Bahan yang digunakan untuk pembuatan sosis yaitu daging ayam bagian dada, gula pasir, bawang putih bubuk, garam, lada, susu skim, tepung tapioka, khitosan, angkak, air es, dan casing sosis. Uji aktivitas antibakteri, karakteristik mikrobiologi memerlukan yeast extract, agar, $\mathrm{NaCl}$, aquadest, biakan bakteri Escherichia coli dan Staphylococcus aureus dengan koloni minimal $10^{6}$ $\mathrm{CFU} / \mathrm{ml}$, violet red bile agar, salmonella shigella agar. Uji karakteristik kimia $\mathrm{K}_{2} \mathrm{SO}_{4}, \mathrm{CuSO}_{4}, \mathrm{H}_{2} \mathrm{SO}_{4}$ pekat, indikator phenolphthalein, asam borat, $\mathrm{HCl}$, methanol, dan larutan 1,1,2,2-diphenyl picryl hydrazyl.

\section{Metode}

Pengujian aktivitas antibakteri asam asetat, khitosan, dan angkak. Aktivitas antibakteri asam asetat, khitosan, dan angkak $(0,5 ; 1 ; 1,5 ; 2 \%)$ diuji menggunakan metode sumuran dengan biakan bakteri S.aureus (Gram positif) dan E.coli (Gram negatif) dengan koloni minimal $10^{6} \mathrm{CFU} / \mathrm{ml}$ (Hudzicki, 2009).

Pembuatan sosis. Daging ayam bagian dada digiling (PT Royan Yogyakarta), dicampur garam, gula pasir, merica, bawang putih powder, skim milk, tepung tapioka, angkak dan khitosan (DD 85,05\%). Perbandingan pemberian angkak $0 ; 0,5 ; 1 ; 1,5 ; 2 \%$ (b/b) dan khitosan $0 ; 0,5 ; 1 ; 1,5 ; 2 \%$ (b/v) yang telah dilarutkan dalam asam asetat $1 \%$. Adonan dilembutkan menggunakan copper dengan penambahan air es sedikit demi sedikit, dimasukkan ke dalam casing dan dikukus selama 30 menit. Sosis dikemas menggunakan plastik (polypropylene) dan divakum, disimpan dalam refrigerator suhu $\pm 4^{\circ} \mathrm{C}$ pada hari ke- $0,7,14$, dan 21 diambil sampel untuk pengujian karakteristik mikrobiologi dan kimia sosis.

Pengujian karakteristik mikrobiologi. Uji Enterobacteriaceae dengan medium Violet Red Bile Agar dan Salmonella dengan medium Salmonella Shigellla Agar menggunakan metode pour plate (Fardiaz, 1993).

Pengujian karakteristik kimia. Uji kadar air dan kadar lemak (AOAC, 2005), kadar protein dengan metode Kjeldahl (Sudarmadji et al., 1997), dan aktivitas antioksidan diphenyl picryl hydrazyl (DPPH) (Yen dan Chen, 1995).

\section{Analisis data}

Data aktivitas antibakteri dianalisis dengan Randomized Completely Block Design (RCBD), Enterobacteriaceae dengan One-Way ANOVA, karakteristik kimia dan mikrobiologi dianalisis dengan analisis variansi pola faktorial $4 \times 5$ dengan faktor lama penyimpanan dan kombinasi 
konsentrasi khitosan:angkak dan dilanjutkan dengan Duncan's Multiple Range Test (DMRT) (Astuti, 1981).

\section{Hasil dan Pembahasan}

Aktivitas antibakteri asam asetat, khitosan, dan angkak

Aktivitas antibakteri asam asetat. Konsentrasi asam asetat (Tabel 1) dan perbedaan jenis bakteri (Tabel 2) menunjukkan perbedaan yang sangat nyata $(\mathrm{P}<0,01)$ terhadap aktivitas antibakteri. Beuchat dan Golden (1999) cit. Ewadh et al. (2013) menyatakan bahwa asam asetat baik murni ataupun cuka, memiliki pengaruh pada pertumbuhan berbagai jenis bakteri, pada $\mathrm{pH}$ yang sama penghambatan yang diperoleh lebih besar dengan meningkatnya konsentrasi asam asetat.

Booth dan Kroll (1989) cit. Brul dan Coote (1999) menyatakan bahwa mekanisme penghambatan asam organik terhadap pertumbuhan mikroorganisme adalah kemampuan terdisosiasi (terurai) asam untuk berdifusi bebas melintasi membran sel (lipid bilayer) dan membebaskan proton dalam sitoplasma. Asam akan memisahkan diri karena keadaan di dalam sel memiliki pH yang lebih tinggi dari di luar sel, maka proton yang dihasilkan dari pemisahan intraseluler asam organik membuat suasana asam dari sitoplasma dan menurunkan $\mathrm{pH}$ sitoplasma.

Aktivitas antibakteri khitosan. Konsentrasi khitosan (Tabel 1) dan perbedaan jenis bakteri (Tabel 2) menunjukkan perbedaan yang nyata $(\mathrm{P}<0,05)$ terhadap aktivitas antibakteri, hal ini disebabkan karena semakin banyak muatan positif (gugus $\mathrm{NH}^{3+}$ ) dalam larutan, akibat dari gugus amina $\left(\mathrm{NH}_{2}\right)$ yang bebas dalam larutan asam (asam asetat) yang terprotonisasi membentuk muatan positif. Khitosan bermuatan positif efektif berinteraksi dengan molekul bermuatan negatif yang terdapat pada membran sel bakteri. Interaksi tersebut mengakibatkan perubahan permeabilitas membran sel, sehingga terjadi ketidakseimbangan osmotik internal sel yang mengakibatkan pertumbuhan mikroorganisme terhambat. Helander et al. (2001) mengungkapkan bahwa khitosan mengikat membran luar dan menghilangkan fungsi barier membran sel.

Antibakteri khitosan lebih sensitif terhadap Gram negatif dibandingkan Gram positif. Shahidi $e t$ al. (1999) menyatakan bahwa khitosan menghambat pertumbuhan bakteri melalui interaksi antara muatan positif (gugus $\mathrm{NH}^{3+}$ ) pada molekul khitosan dengan muatan negatif pada membran sel menyebabkan lepasnya unsur protein dan unsur lain penyusun intraseluler.

Aktivitas antibakteri angkak. Konsentrasi angkak (Tabel 1) dan perbedaan jenis bakteri (Tabel 2) tidak menunjukkan adanya aktivitas antibakteri. Konsentrasi angkak hingga 2\% tidak mampu menghambat pertumbuhan bakteri $S$. aureus maupun E. coli, hal ini dapat terjadi karena rendahnya kadar citrinin (zat antibakteri) dan populasi bakteri yang cukup banyak mengakibatkan bakteri dapat berkembang tanpa adanya tekanan dari antibakteri. Fluit et al. (2001) menyatakan bahwa mekanisme bakteri untuk memperoleh resistensi antara lain pengurangan penyerapan zat antibakteri, kehabisan bahan aktif antibakteri, dan kelebihan dari target agen antibakteri. Arestrup et al. (2001) cit. Byarugaba (2009) menyatakan bahwa tingkat resistensi dapat disebabkan oleh populasi mikroorganisme yang secara spontan memperoleh mekanisme resistensi sebagai hasil dari tekanan lingkungan. Sifat zat antibakteri angkak adalah bakteriostatik yang menghambat pertumbuhan bakteri, sehingga terdapat kemungkinan bakteri yang bertahan hidup dapat tumbuh dan berkembang. Berdasarkan pernyataan tersebut tidak adanya aktivitas antibakteri pada angkak dapat

Tabel 1. Rerata aktivitas antibakteri pada level asam asetat, khitosan dan angkak (mm) (average of antibacterial activity of acetic acid, chitosan and anka rice level $(\mathrm{mm})$ )

\begin{tabular}{|c|c|c|c|c|}
\hline \multirow[t]{2}{*}{ Variabel (variable) } & \multicolumn{4}{|c|}{$\begin{array}{l}\text { Level asam asetat, khitosan, dan angkak (\%) (acetat acid, chitosan and } \\
\text { anka rice level (\%)) }\end{array}$} \\
\hline & 0,5 & 1 & 1,5 & 2 \\
\hline Asam asetat (acetic acid) & $13,47 \pm 2,22^{\mathrm{a}}$ & $14,42 \pm 1,47^{\mathrm{a}}$ & $20,38 \pm 5,73^{b}$ & $24,70 \pm 3,53^{\mathrm{c}}$ \\
\hline Khitosan (chitosan) & $10,91 \pm 1,16^{\mathrm{d}}$ & $12,33 \pm 0,85^{\mathrm{de}}$ & $13,35 \pm 1,87^{\mathrm{ef}}$ & $13,97 \pm 1,05^{\mathrm{f}}$ \\
\hline Angkak (anka rice) & ND & ND & ND & ND \\
\hline 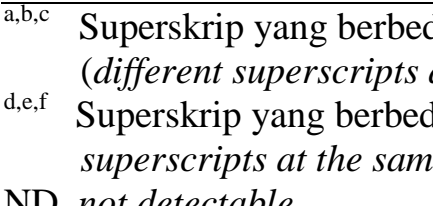 & $\begin{array}{l}\text { baris yan } \\
\text { ume row } i \\
\text { baris yan }\end{array}$ & $\begin{array}{l}\text { nenunjukk: } \\
\text { significant } \\
\text { nenunjukka }\end{array}$ & $\begin{array}{l}\text { bedaan yang } \\
\text { lifferences ( } I \\
\text { bedaan yang }\end{array}$ & $\begin{array}{l}\text { ata }(\mathrm{P}<0,01) \\
0,05)(\text { different }\end{array}$ \\
\hline
\end{tabular}


Tabel 2. Rerata aktivitas antibakteri asam asetat, khitosan dan angkak pada bakteri yang berbeda (mm) (average of antibacterial activity of acetic acid, chitosan and anka rice in different bacteria $(\mathrm{mm})$ )

\begin{tabular}{lcc}
\hline \hline & \multicolumn{2}{c}{ Jenis bakteri (types of bacteria) } \\
\cline { 2 - 3 } Variabel (variable) & Escherichia coli & Staphylococus aureus \\
\hline Asam asetat (acetic acid) & $21,07 \pm 5,99^{\mathrm{p}}$ & $15,47 \pm 4,10^{\mathrm{q}}$ \\
Khitosan (chitosan) & $13,24 \pm 1,51^{\mathrm{r}}$ & $12,11 \pm 1,75^{\mathrm{s}}$ \\
Angkak (anka rice) & $\mathrm{ND}$ & $\mathrm{ND}$ \\
\hline $\mathrm{p}, \mathrm{q}$ & Superskrip yang berbeda pada baris yang sama menunjukkan perbedaan yang sangat nyata $(\mathrm{P}<0,01)$ \\
& (different superscripts at the same row indicate significant very differences $(P<0.01))$. \\
$\mathrm{r}, \mathrm{s}$ & Superskrip yang berbeda pada baris yang sama menunjukkan perbedaan yang nyata $(\mathrm{P}<0,05)($ different \\
superscripts at the same row indicate significant differences $(P<0.05))$. & \\
$\mathrm{ND}$ & not detectable.
\end{tabular}

disebabkan karena bahan aktif antibakteri belum mampu bersifat bakteriostatik dan kelebihan dari target antibakteri.

\section{Karakteristik mikrobiologi sosis}

Enterobacteriaceae. Pemberian khitosan dan angkak tidak menunjukkan perbedaan yang nyata terhadap Enterabacteriaceae (Tabel 3). Mattick et al. (2001) menjelaskan bahwa perlakuan panas pada $55^{\circ} \mathrm{C}$ selama 10 menit dapat menghancurkan bakteri yang bersifat psikrofilik dan sensitif terhadap panas, sedangkan bakteri tahan panas dan tidak membentuk spora, termasuk Enterococci dan Lactobacili akan hancur pada $65^{\circ} \mathrm{C}$. Pendinginan dengan metode suhu rendah bertujuan untuk memperlambat atau membatasi laju pembusukan di bawah suhu optimal yang dapat menghambat pertumbuhan mikroba (Cassens, 1994). Bhattacharyya et al. (2013) sosis yang dikemas secara vakum menciptakan lingkungan yang tidak menguntungkan bagi pertumbuhan mikroba dalam produk olahan.

Populasi Enterobacteriaceae terdeteksi pada hari ke-21, tetapi jumlah koloni tidak memenuhi standar yaitu <30,0 × $10^{1} \mathrm{CFU} / \mathrm{g}$ (Tabel 4). Temperatur rendah menciptakan lingkungan yang tidak nyaman bagi pertumbuhan bakteri, akan tetapi bakteri masih dapat berkembang walaupun dengan kecepatan yang rendah. Stoecker (1998) me- nyatakan bahwa suhu dingin memperlambat proses kimia dan biologi dalam makanan dan kerusakan yang menyebabkan penurunan kualitas nutrisi.

Salmonella. Level penambahan khitosan dan angkak tidak menunjukkan adanya populasi Salmonella (Tabel 3). Sosis mengalami proses pengukusan pada air mendidih yang dapat mematikan bakteri. Sosis disimpan dalam keadaan vakum memungkinkan tidak terjadinya kontaminasi dari lingkungan luar masuk ke dalam kemasan, meskipun tidak diberi angkak dan khitosan. Brewer (1991) menyatakan bahwa pertumbuhan Salmonella dapat dicegah dengan memasak makanan secara menyeluruh. Beberapa bakteri memiliki ketahanan terhadap panas, tetapi beberapa spesies membutuhkan 10 sampai 15 menit pada suhu $65^{\circ} \mathrm{C}$ untuk membunuh $90 \%$ dari populasi, oleh karena itu dengan pemasakan hinggga $100^{\circ} \mathrm{C}$ akan membunuh bakteri termasuk Salmonella.

Lama penyimpanan tidak menunjukkan adanya pertumbuhan Salmonella (Tabel 4). Penyimpanan suhu rendah merupakan keadaan dan lingkungan yang tidak mendukung pertumbuhan Salmonella. Proses pemasakan sebelum penyimpanan dapat membunuh bakteri sehingga pada hari ke-0 tidak terdapat populasi Salmonnella hingga penyimpanan hari ke-21. Salmonella spp. rentan terhadap berbagai desinfektan, dapat dimatikan dengan panas $\left(121^{\circ} \mathrm{C}\right.$ selama 15 menit

Tabel 3. Rerata Enterobacteriaceae dan Salmonella sosis ayam dengan level penambahan khitosan dan angkak $\left(10^{1} \mathrm{CFU} / \mathrm{g}\right)$ (average of Enterobacteriaceae and Salmonella of chicken sausage with chitosan and anka rice addition $\left.\left(10^{l} \mathrm{CFU} / \mathrm{g}\right)\right)$

\begin{tabular}{lccccc}
\hline \hline \multirow{2}{*}{ Variabel (variable) } & \multicolumn{5}{c}{ Level khitosan dan angkak (\%) $($ chitosan and anka rice level $(\%))$} \\
\cline { 2 - 5 } & 0 & 0,5 & 1 & 1,5 & 2 \\
\hline Enterobacteriaceae $^{\mathrm{ns}}$ & $4,5^{*}$ & $6,0^{*}$ & $7,0^{*}$ & $3,6^{*}$ & $1,2^{*}$ \\
Salmonella & $\mathrm{ND}$ & $\mathrm{ND}$ & $\mathrm{ND}$ & $\mathrm{ND}$ & $\mathrm{ND}$ \\
\hline$*\left(<30,0 \times 10^{1} \mathrm{CFU} / \mathrm{g}\right)$ & ${ }^{\mathrm{ns}}$ &
\end{tabular}

$*\left(<30,0 \times 10^{1} \mathrm{CFU} / \mathrm{g}\right),{ }^{\mathrm{ns}}$ berbeda tidak nyata (non significant), ND not detectable. 
Tabel 4. Rerata Enterobacteriaceae dan Salmonella sosis ayam yang disimpan sampai 21 hari pada refrigerator $\left(10^{1} \mathrm{CFU} / \mathrm{g}\right)$ (average of Enterobacteriaceae and Salmonella of chicken sausage stored up to 21 days in the refrigerator $\left.\left(10^{l} \mathrm{CFU} / \mathrm{g}\right)\right)$

\begin{tabular}{lcccc}
\hline \hline \multirow{2}{*}{ Variabel (variable) } & \multicolumn{4}{c}{ Lama penyimpanan (hari) (storage time (day)) } \\
\cline { 2 - 5 } & 0 & 7 & 14 & 21 \\
\hline Enterobacteriaceae & ND & ND & ND & $4,5^{*}$ \\
Salmonella & ND & ND & ND & ND \\
\hline
\end{tabular}

* $\left(<30,0 \times 10^{1} \mathrm{CFU} / \mathrm{g}\right), \mathrm{ND}$ not detectable.

atau panas kering $\left(160-170^{\circ} \mathrm{C}\right.$ selama setidaknya 1 jam) (Center for Food Security and Public Health, 2005). Penyimpanan suhu rendah merupakan salah satu metode pengawetan produk olahan daging. Brody (2000) menyatakan bahwa pengemasan bertujuan mencegah masuknya kembali mikroorganisme setelah proses penghilangan (pemasakan) kembali, meminimalkan probabilitas penyakit, infeksi dari makanan, dan mengurangi pembusukan yang dapat menyebabkan toksin.

\section{Karakteristik kimia sosis}

Kadar air. Penambahan khitosan dan angkak menunjukkan perbedaan yang nyata $(\mathrm{P}<0,05)$ (Tabel 5) terhadap kadar air. Sosis ayam kontrol memiliki kadar air lebih tinggi dibandingkan sosis ayam perlakuan. Hal ini dapat disebabkan karena kemampuan protein menahan air pada sosis kontrol lebih tinggi dibandingkan dengan sosis perlakuan. Swatland (2000) menyatakan bahwa kapasitas menahan air (water-holding capasity) adalah kemampuan daging untuk mempertahankan air, sedangkan kapasitas mengikat air (water-binding capacity) adalah kemampuan daging mengikat air yang ditambahkan ke dalam produk. Air yang ditambahkan ke dalam sosis saat proses pembuatan jumlahnya sama, tetapi air yang ditambahkan pada sosis perlakuan berbentuk gel. Kemampuan protein mengikat air dalam bentuk larutan atau gel berbeda, sehingga meningkatnya penambahan khitosan kandungan kadar airnya lebih sedikit (Swatland, 2000).

Lama penyimpanan sampai 21 hari tidak menunjukkan perbedaan yang nyata (Tabel 6) terhadap kadar air. Kadar air tidak berubah selama penyimpanan disebabkan sosis disimpan dalam refrigerator dan dikemas vakum. Pengemasan vakum menjaga agar air tidak masuk ke dalam produk, sehingga tidak mempengaruhi kadar air. Brody (2000) menyatakan bahwa produk harus dilindungi untuk mengontrol kadar air. Sebagian besar produk kering bersifat higroskopis dapat menyerap air, sebaliknya produk basah rentan terhadap hilangnya kadar air.
Kadar protein. Penambahan khitosan dan angkak tidak menunjukkan perbedaan yang nyata (Tabel 5) terhadap kadar protein. Air merupakan komponen yang dapat melepaskan diri karena proses pemanasan. Air yang keluar pada proses pemasakan pada suhu tinggi keluar tidak seorang diri, melainkan membawa nutrien lain yang larut air seperti protein. Menurut Lehninger (1982), berdasarkan gugus $\mathrm{R}$ asam amino dapat digolongkan berdasarkan polaritasnya, mulai dari gugus $\mathrm{R}$ yang sama sekali tidak polar atau hidrofobik sampai bersifat polar atau hidrofilik. Peningkatan komponen pada suatu bahan mengakibatkan penurunan pada komponen lain. Penelitian Ismail et al. (2011) menunjukkan bahwa meningkatnya kadar air pada sosis bebek menyebabkan menurunnya kadar protein dan kadar lemak.

Lama penyimpanan tidak menunjukkan perbedaan yang nyata (Tabel 6) terhadap kadar protein. Kadar air tidak berubah selama penyimpanan mengakibatkan kadar protein tidak berubah selama penyimpanan. Pengemasan vakum menghasilkan tingkat oksigen yang rendah dalam kemasan tertutup. Lingkungan anaerobik pada kemasan vakum mencegah pertumbuhan mikroorganisme pembusuk terutama anaerobik yang bertanggungjawab terhadap timbulnya bau, lendir, dan tekstur yang berubah (Nunez et al., 1986).

Kadar lemak. Penambahan khitosan dan angkak tidak menunjukkan perbedaan yang nyata (Tabel 5) terhadap kadar lemak. Hal ini disebabkan karena aktivitas antioksidan yang meningkat seiring dengan peningkatan level khitosan dan angkak, sehingga mencegah terjadinya oksidasi lemak, dengan demikian menjaga kualitas lemak. Khine et al. (2011) menyatakan bahwa dengan meningkatnya konsentrasi antioksidan yang ditambahkan daya hambat oksidasi lemak semakin meningkat, dengan meningkatnya daya hambat, maka aktivitas antioksidan juga meningkat untuk menghambat terjadinya oksidasi lemak.

Lama penyimpanan sampai 21 hari di refrigerator tidak menunjukkan perbedaan yang nyata (Tabel 6) terhadap kadar lemak. Hal ini 
Tabel 5. Rerata karakteristik kimia sosis ayam dengan level penambahan khitosan dan angkak (\%) (average of characteristic quality of chicken sausage with chitosan and anka rice addition (\%))

\begin{tabular}{|c|c|c|c|c|c|}
\hline \multirow{2}{*}{ Variabel (variable) } & \multicolumn{5}{|c|}{ Level khitosan dan angkak (\%) (chitosan and anka rice level (\%)) } \\
\hline & 0 & 0,5 & 1 & 1,5 & 2 \\
\hline $\begin{array}{l}\text { Kadar air (moisture } \\
\text { content) }\end{array}$ & $68,24 \pm 0,97^{\mathrm{c}}$ & $68,03 \pm 0,57^{\mathrm{c}}$ & $67,83 \pm 0,71^{\mathrm{bc}}$ & $67,15 \pm 0,87^{\mathrm{ab}}$ & $66,78 \pm 0,90^{\mathrm{a}}$ \\
\hline $\begin{array}{l}\text { Kadar protein (protein } \\
\text { content) }^{\mathrm{ns}}\end{array}$ & $15,62 \pm 0,77$ & $15,02 \pm 1,17$ & $15,19 \pm 0,76$ & $15,57 \pm 0,99$ & $15,49 \pm 1,15$ \\
\hline Kadar lemak $(\text { fat content })^{\mathrm{ns}}$ & $0,64 \pm 0,13$ & $0,60 \pm 0,14$ & $0,55 \pm 0,05$ & $0,60 \pm 0,08$ & $0,57 \pm 0,05$ \\
\hline $\begin{array}{l}\text { Aktivitas antioksidan } \\
\text { (antioxidant activity) }\end{array}$ & $13,91 \pm 2,75^{\mathrm{a}}$ & $14,32 \pm 2,56^{\mathrm{a}}$ & $14,92 \pm 2,63^{\mathrm{ab}}$ & $15,68 \pm 2,41^{\mathrm{b}}$ & $15,83 \pm 2,87^{\mathrm{b}}$ \\
\hline
\end{tabular}

Tabel 6. Rerata karakteristik kimia sosis ayam yang disimpan sampai 21 hari pada refrigerator (\%) (average of chemical characteristic of chicken sausage stored up to 21 days in the refrigerator (\%))

\begin{tabular}{|c|c|c|c|c|}
\hline \multirow{2}{*}{ Variabel (variable) } & \multicolumn{4}{|c|}{ Lama penyimpanan (hari) (storage time (day)) } \\
\hline & 0 & 7 & 14 & 21 \\
\hline Kadar air (moisture content $)^{\mathrm{ns}}$ & $67,88 \pm 0,80$ & $67,58 \pm 0,95$ & $67,40 \pm 1,21$ & $67,55 \pm 0,90$ \\
\hline Kadar protein $(\text { protein content })^{\mathrm{ns}}$ & $15,12 \pm 1,24$ & $15,42 \pm 0,81$ & $15,14 \pm 1,15$ & $15,84 \pm 0,41$ \\
\hline Kadar lemak $(\text { fat content })^{\mathrm{ns}}$ & $0,56 \pm 0,07$ & $0,60 \pm 0,08$ & $0,57 \pm 0,07$ & $0,64 \pm 0,15$ \\
\hline Aktivitas antioksidan (antioxidant activity) & $12,21 \pm 1,17^{\mathrm{a}}$ & $13,61 \pm 1,35^{\mathrm{b}}$ & $18,46 \pm 1,32^{\mathrm{c}}$ & $15,44 \pm 1,30^{\mathrm{d}}$ \\
\hline
\end{tabular}

disebabkan karena pengemasan sosis dalam keadaan vakum, oksigen telah dikeluarkan pada kemasan tertutup sehingga dapat mencegah terjadinya perubahan secara kimiawi termasuk lemak. Brody (2000) menyatakan bahwa oksigen di dalam udara bereaksi dengan sebagian besar produk makanan. Dengan membangun penghalang antara udara dan produk pangan, pengepakan dapat menghambat oksidasi lemak dan kerusakan kimiawi pada produk makanan.

Aktivitas antioksidan. Penambahan khitosan:angkak menunjukkan perbedaan nyata $(\mathrm{P}<0,05)$ (Tabel 5) terhadap aktivitas antioksidan. Tisnadjaja dan Bustanussalam (2012) menyatakan bahwa kandungan senyawa antikolesterol beras merah hasil fermentasi (angkak) memiliki kandungan senyawa bersifat antioksidan. Oleh karena itu dengan meningkatnya penambahan angkak, maka aktivitas antioksidan semakin meningkat.

Lama penyimpanan menunjukkan perbedaan yang sangat nyata $(\mathrm{P}<0,01)$ (Tabel 6) terhadap aktivitas antioksidan. Oksidasi lemak dapat terjadi karena adanya oksigen. Sosis ayam yang disimpan dalam refrigerator sampai 21 hari dikemas secara vakum. Akan tetapi, alat pengemasan yang digunakan masih berskala laboratorium, sehingga dimungkinkan terdapat oksigen yang tersisa. Fennema (1996) cit. Cottone (2009) menyatakan bahwa lemak yang mengandung asam lemak tidak jenuh dan esternya akan mudah teroksidasi oleh adanya molekul oksigen. Reaksi dengan molekul oksigen melalui mekanisme self-catalytic yang disebut auto-oxidation. Inisiasi oleh auto-oxidation dapat dimulai oleh dekomposisi hidrogen peroksida, katalisis logam, paparan cahaya, atau kontak dengan singlet oxygen.

\section{Kesimpulan dan Saran}

\section{Kesimpulan}

Kesimpulan dari penelitian ini adalah penambahan khitosan dan angkak sampai level 2\% meningkatkan aktivitas antibakteri khitosan dan aktivitas antioksidan, tetapi menurunkan kadar air. Lama penyimpanan sosis ayam sampai 21 hari meningkatkan aktivitas antioksidan dan aroma sosis. Total Enterobacteriaceae terdeteksi pada hari ke-21 tetapi populasi masih sangat rendah, sedangkan Salmonella tidak terdeteksi sampai hari 
ke-21. Penyimpanan sosis ayam pada refrigerator sampai 21 hari masih layak untuk dikonsumsi.

\section{Saran}

Khitosan dapat digunakan sebagai bahan pengawet alami. Kombinasi penyimpanan sosis pada suhu rendah, kemasan vakum, dan tambahan bahan pengawet alami dapat mempertahankan kualitas sosis. Angkak dapat digunakan sebagai pewarna alami pengganti nitrit pada pembuatan sosis.

\section{Daftar Pustaka}

AOAC. 2005. Official Methods of Analysis of The Association of Analytical Chemists. Washington D.C.

Astuti, M. 1981. Rancangan Percobaan dan Analisis Statistik. Bagian Pemuliaan Ternak, Fakultas Peternakan, Universitas Gadjah Mada. Yogyakarta.

Bhattacharyya, D., M. Sinhamahapatra and S. Biswas. 2013. Effect of packing materials and methods on physical properties and food safety of duck sausage. Int. J. Dev. Res. 3: 032-040.

Brewer, M. S. 1991. Food Storage, Food Spoilage, and Food Iillness. University of Illinois at Urbanna-Champaign. College of Agricultural, Consumer and Enviromental Science. Champaign.

Brody, A. L. 2000. Developing new Food Product for Changing Marketplace: Development of Packaging for Product. CRC Press Inc. United States.

Brul, S. and P. Coote. 1999. Review: Preservative agents in foods: Mode of action and microbial resistance mechanism. Int. J. Food Microbiol. 50: 1-7.

Busboom, J. R. and R. A. Field. 2003. Homemade Meat, Poultry and Game Sausage. Washington State University. Washington.

Byarugaba, D. K. 2009. Mechanism of Antimicrobial Resistance. Departement of Vetenary Microbiology and Parasitology, Faculty of Veteinary Medicine, Makerere University, Kampala. Uganda.

Cassens, R. G. 1994. Meat Preservation, Preventing Losses and Assuring Safety. $1^{\text {st }}$ ed. Food and Nutrition Press, Inc. Trumbull, Connecticut.

Center for Food Security and Public Health. 2005. Salmonellosis. Institute for International Cooperation in Animal Biologics. Iowa State University. Iowa.
Cottone, E. 2009. Use of Natural Antioxidant in Diary and Meat Product: A Reviews of Sensory and Instrumental Analyses. Food Science. Kansas State University. Kansas.

Ewadh, M., H. Hasan, I. Buyan, F. Mousa, J. Sultan and M. Ewadh. 2013. Antibacterial activity of 2-(2-Hydroxy phenylimino) acetic acid. Life Sci. Technol. 7: 15-20.

Fardiaz, S. 1993. Analisis Mikrobiologi Pangan. PAU Pangan dan Gizi, Institut Pertanian Bogor. Bogor.

Fluit, A. D., R. Maarten, R. Visser and F. J. Schmitz. 2001. Molecular detection of antimicrobial resistence. Clin. Microbiol. Rev. 14: 836-871.

Gremmels, F. J., J. Dresel and L. Leistner. 1991. Use of Monascus extracts as an alternative to nitrite in meat product. Fleischwirtschaft. 71: 329-331.

Hajjaj, H., A. Klaebe, A. O. Loret, G. Goma, P. G. Blanc and J. Francois. 1999. Biosynthetic pathway of citrinin in the filamentous fungus Monascus ruber as revealed by $13 \mathrm{C}$ nuclear magnetic resonance. Appl. Environ. Microbiol. 65: 311-314.

Helander, I. M., E. L. N. Lassila, R. Ahvenainen, J. Rhoade and S. Roller. 2001. Chitosan distrupts the barier properties of the outer membran of Gram-negative bacteria. Int. J. Food Microbiol. Rev. 71: 235-244.

Hudzicki, J. 2009. Kirby-Bauer Disk Diffusion Susceptibility Test Protocol. Available at http://microbelibrary.org/component/resource /laboratory-test/3189-kirby-bauer-diskdiffusion-susceptibility-test-protocol. Accession date: September 28, 2012.

Ismail, I., N. Huda and R. Ahmad. 2011. Funtional properties of low-fat duck sausage formulated with palm oil. Asian J. Food Agro-Industry 4: 222-232.

Khine, K. H., M. M. Aye and M. H. Ngwe. 2011. Some chemical analyses and determination of antioxidant property of Neem Leaf (Azadirachita indica A. Juss). Universities Res. J. 4: 227-235.

Lehninger, A. L. 1982. Dasar-dasar Biokimia Jilid 1. Alih bahasa M. Thenawidjaja. Erlangga. Jakarta.

Li, Q., E. T. Dunn, E. W. Grandmaison and M. F. A. Goosen. 1992. Applications and properties of chitosan. J. Bioact. Compat. Polym. 7: 370-397.

Mattick, K. L., F. Jorgensen and P. Wang. 2001. Effect of challenge temperature and solute type on heat tolerance of Salmonella serovars at low water activity. Appl. Environ. Microbiol. 67: 4128-4136. 
Nunez, M. P., M. Gaya, M. Madena, M. A. Rodriguezmarian and A. C. Garcia. 1986. Changes in microbiological, chemical, rheological and sensory characteristics during ripening of vacuum packaged Manchego cheese. J. Food Sci. 21: 115-123.

Shahidi, F., J. K. V. Arachchi and Y. J. Jeon. 1999. Food applications of chitin and chitosans. Trends Food Sci. Technol. 10: 37-51.

Stoecker, W. F. 1998. Industrial Refrigeration Handbook: the Refrigeration and Freezing of Food. The McGraw-Hill Companies, Inc.

Sudarmadji, S., B. Haryono, dan Suhardi. 1997. Prosedur Analisa untuk Bahan Makanan dan Pertanian. Liberty. Yogyakarta.

Suyatma, N. E., A. Copinet, V. Coma and L. Tighzert. 2004. Mechanical and barrier properties of biodegradable films based on chitosan and poly (lactic acid) for food packaging application. J. Polym. Environ. 12: $1-12$.
Swatland, H. J. 2000. Meat Processing Improving Quality: On-line Monitoring of Meat Quality. Woodhead Publishing Limited. England.

Tisnadjaja, D. dan Bustanussalam. 2012. Hubungan profil kromatografi dari ekstrak angkak dengan aktivitas antioksidannya. Prosiding Seminar Nasional XXI Kimia dalam Industri dan Lingkungan. Yogyakarta.

Yen, G. C. and H. Y. Chen. 1995. Antioxidants activity of various tea extracts in relation to their antimutagenicity. J. Agric. Food Chem. 43: 383-386. 